\title{
PERBANDINGAN KEMAMPUAN BERPIKIR KREATIF MATEMATIKA SISWA ANTARA YANG MENGGUNAKAN PENILAIAN TUGAS DENGAN PENILAIAN PORTOFOLIO DALAM PEMBELAJARAN MATEMATIKA
}

\author{
Yunus Sunandar, Arif Muchyidin \\ Tadris Matematika, IAIN Syekh Nurjati Cirebon \\ Jalan perjuangan Bypass Sunyaragi
}

\begin{abstract}
$A B S T R A C T$
This study aimed to determine whether there are significant differences in mathematical thinking ability of students who use the assessment tasks with portfolio assessment. This research was conducted in class VIII B and VIII D SMPN 2 Cirebon. The sampling technique using random sampling techniques, with samples of 45 students for group assessment tasks $\left(X_{1}\right)$ and 45 students for portfolio valuation group $\left(X_{2}\right)$. The instrument used in this study are shaped test of 10 questions about the description. The results obtained by the mathematical creative thinking ability of students to use the assessment task has an average of 74.31 with a median and mode respectively 74.00 and 70.00. While the ability to think creatively mathematics students using portfolio assessment has an average of 79.69 with a median and mode respectively 80.00 and 82.00. Of hypothesis testing via $t$ test obtained $t_{\text {count }}<t_{\text {table }}$ ie $t_{\text {count }}=-4.557$, while $t_{\text {table }}=1.987$, This case shows that there are no significant differences in mathematics creative thinking ability of students between the use of assessment tasks with portfolio assessment in mathematics
\end{abstract}

Keywords : : : : $\quad$ ssessment Task, Portfolio Assessment, and Creative Thinking Skills Mathematics

\section{PENDAHULUAN}

Upaya meningkatkan kualitas pendidikan terus-menerus dilakukan baik secara konvensional maupun inovatif. Hal tersebut lebih fokus lagi setelah dimanfaatkan bahwa tujuan pendidikan nasional adalah untuk meningkatkan mutu pada jenis dan jenjang pendidikan. Upaya tersebut, antara lain dengan dikeluarkannya Undang-undang Sistem Pendidikan Nasional pada Tahun 2003, dan Peraturan Pemerintah No. 19 Tahun 2005 tentang Standar Nasional Pendidikan (SNP), yang telah dilakukan penataan kembali dalam Peraturan Pemerintah No. 32 Tahun 2013 (Mulyasa, 2013 : 4).

Pendidikan pada hakikatnya bertujuan untuk meningkatkan kualitas hidup manusia yang secara teknis operasional dilakukan melalui pembelajaran. Proses pembelajaran idealnya bukan sekedar berdampak pada keberhasilan pembelajar menghadapi pembelajaran, tetapi juga kemampuan menghadapi kehidupan (Nurhayati, 2011 : 65)

Berkaitan dengan perubahan kurikulum, berbagai pihak menganalisis dan melihat perlunya diterapkan kurikulum berbasis kompetensi sekaligus berbasis karakter (competency and character based curriculum), yang dapat membekali peserta didik dengan berbagai sikap dan kemampuan yang sesuai dengan tuntunan perkembangan zaman dan tuntunan teknologi. Kurikulum berbasis karakter dan kompetensi diharapkan mampu memecahkan berbagai persoalan bangsa, khususnya dalam bidang pendidikan, dengan mempersiapkan peserta didik, melalui perencanaan, pelaksanaan, dan evaluasi terhadap sistem pendidikan secara efektif, efisien, dan berhasil berguna (Mulyasa, 2013 : 6).

Kurikulum, proses pembelajaran, dan penilaian merupakan tiga dimensi dari sekian banyak dimensi yang sangat penting dalam pendidikan. Ketiga dimensi tersebut saling berkaitan antara satu dengan yang lainnya. Kurikulum merupakan penjabaran tujuan pendidikan yang menjadi landasan program pembelajaran. Proses pembelajaran merupakan upaya yang dilakukan guru untuk mencapai tujuan yang dirumuskan dalam kurikulum. Penilaian merupakan salah satu kegiatan yang dilakukan untuk 
mengukur dan menilai tingkat pencapaian kurikulum dan berhasil tidaknya proses pembelajaran. Penilaian juga digunakan untuk mengetahui kekuatan dan kelemahan yang ada dalam proses pembelajaran, sehingga bisa dijadikan sebagai dasar untuk keputusan, misalnya apakah proses pembelajaran sudah baik dan dapat dilanjutkan atau masih perlu diperbaiki dan penyempurnaan (Surapranata dan Hatta, $2004: 1)$.

Perubahan kurikulum juga membawa implikasi terjadinya perubahan penilaian. Perubahan penilaian dimaksud pada penilaian pendekatan norma kepenilaian yang menggunakan acuan kriteria dan dan standar, yaitu aspek yang menunjukan seberapa kompeten peserta didik menguasai materi yang telah di ajarkan (Surapranata dan Hatta, 2004 : 2).

Belajar untuk belajar adalah sebuah konsep yang berupaya membelajarkan individu bagaimana mengembangkan daya kecerdasan dan daya kreativitasnya. Untuk melahirkan lulusan dengan keterampilan memadai, menurut Dost (2000 : 128) sebagaimana yang dikutip oleh Nurhayati, tugas lembaga pendidikan bukan sekedar memberi yang dikehendaki oleh masyarakat, melainkan yang dibutuhkan masyarakat. Salah satu kecakapan yang perlu dikembangkan melalui proses pendidikan adalah kecakapan berpikir. Kemampuan seseorang untuk berhasil dalam kehidupannya antara lain ditentuksn oleh kecakapan berpikirnya, terutama dalam upaya memecahkan masalah-masalah kehidupan yang dihadapinya (Nurhayati, $2011: 66$ ).

Permasalahan yang mendasar dalam dunia pendidikan kita adalah rendahnya kualitas dalam proses berfikir matematika. Hal ini ditunjukkan pada rendahnya penalaran dan kemampuan dalam memecahkan masalah. Menurut NCTM (2000) proses berfikir matematika dalam pembelajaran matematika meliputi lima kompetensi standar yang utama yaitu kemampuan pemecahan masalah, kemampuan penalaran, kemampuan koneksi, kemampuan komunikasi dan kemampuan representasi. Rendahnya kemampuan ini akan berakibat pada rendahnya kualitas sumber daya manusia, yang ditunjukkan dalam rendahnya kemampuan berfikir kritis dan kreatif. Sehingga perlu adanya upaya untuk meningkatkan kemampuan tersebut (Jazuli, 2009 : 209).

\section{KAJIAN TEORI}

Menurut Beyer (dalam Nurhayati, 2010 : 30) berpikir merupakan suatu keterampilan manusia untuk membuat konsep, menjelaskan sebab akibat, dan membuat keputusan yang tepat. Sedangkan Dewey (dalam Nurhayati, $2010: 30$ ) berpikir merupakan asas membuat keputusan yang melibatkan kesungguhan, keyakinan, kehatihatian dan pertimbangan tertentu sehingga menghasilkan sebuah keputusan yang tepat.

Definisi kemampuan berpikir secara kreatif dilakukan dengan menggunakan pemikiran dalam mendapat idea-idea yang baru, kemungkinan yang baru, ciptaan yang baru berdasarkan kepada keaslian dalam penghasilannya. Ia dapat diberikan dalam bentuk idea yang nyata ataupun abstrak. (Iskandar, $2012: 88$ ).

Bepikir kreatif merupakan sebuah proses yang terjadi di otak dan pikiran yang dilakukan oleh seorang yang kreatif. Proses tersebut memiliki beberapa tahapan yang harus dilalui dan kaidah-kaidah serta dasardasar serta dasar-dasar yang dijadikan acuan. Selain itu, berpikir kreatif juga disebut sebagai keterampilan khusus yang diperoleh oleh seseorang. Ia bisa menggambarkan fitrah tersebut dengan memahami segala hal yang berhubungan dengan proses tersebut. Berpikir kratif adalah sebuah proses otak yang bersifat universal, kompleks dan diatur oleh beberapa elemen, faktor, keterampilan dan metodemetode yang berpengaruh, baik yang meningkatkan ataupun melemahkan proses berpikir kreatif. (Al-Hajjaj, 2010 : 79 - 80).

Guilford (dalam Jamaris, 2013: 81) menjelaskan bahwa kreativitas adalah perpaduan antara berpikir divergen, berpikir konvergen, dan berpikir evaluative. Perpaduan ketiga bentuk pemikiran tersebut diwujudkan dalam bentuk kemampuan untuk menyeimbangkan kemampuan mensintesis, menganalisis dan menerapkan berbagai informasi yang terkumpul untuk memecahkan masalah yang sedang dihadapi. Oleh karena itu, kreativitas dapat diidentifikasikan melalui, fleksibility, fluency atau kelancaran, dan originality atau keaslian atau sentity atau kepekaan dalam merespon situasi yang mengandung masalah.

Penilaian dalam proses pembelajaran antara lain sebagai kegiatan menghimpun fakta-fakta dan dokumen belajar peserta didik yang dapat dipercaya untuk melakukan perbaikan program, apabila kegiatan 
penilaian tersebut termasuk sebagai bagian dari program pembelajaran didalam kelas. Penilaian juga merupakan poses menyimpulkan dan menafsirkan fakta-fakta dan membuat pertimbangan dasar yang profesional untuk mengambil kebijakan pada sekumpulan informasi, yaitu informasi peserta didik. (Surapranata dan Hatta, 2004 : 3).

Proses penilaian mencakup pengumpulan bukti untuk menunjukan pencapaian belajar (ketercapaian kompetensi) dari peserta didik. Menurut Griffin dan Nix (dalam Haryati, 2008 : 15) penilaian adalah suatu pernyataan berdasarkan sejumlah fakta untuk menjelaskan karakteristik seseorang atau sesuatu. Definisi penilaian berhubungan erat dengan setiap bagian dari kegiatan belajar mengajar. Ini menunjukan bahwa proses penilaian tidak hanya menyangkut hasil belajar saja tetapi juga menyangkut semua proses belajar dan mengajar.

Penilaian penugasan (proyek/project) merupakan penilaian untuk mendapatkan gambaran kemampuan menyeluruh / umum secara kontekstual, mengenai kemampuan siswa dalam menerapkan konsep dan pemahaman mata pelajaran tertentu. Penilaian terhadap suatu tugas yang mengandung investigasi harus selesai dalam waktu tertentu. (Muslich, 2011: 105)

Penilaian project merupakan kegiatan penilaian terhadap suatu tugas yang mencakup beberapa kompetensi yang harus diselesaikan oleh peserta didik dalam periode atau waktu tertentu. Tugas tersebut bisa berupa investigasi terhadap suatu proses atau kejadian yang dimulai dari perencanaan, pengumpulan data, pengorganisasian, pengolahan, dan penyajian data. (Haryati, 2007 : 50).

Manfaat penilaian penugasan (Muslich, 2011 : 105) untuk menilai :

a) Keterampilan menyelidiki secara umum,

b) Pemahaman dan pengetahuan siswa dalam bidang tertentu,

c) Kemampuan mengaplikasikan pengetahuan dalam suatu penyelidikan, dan

d) Kemampuan menginformasikan subjek secara jelas.

Kelebihan dan kekurangan penilaian tugas

a) Kelebihan penilaian tugas (Widyantini, $2014: 5-6)$ :

(1) Meningkatkan motivasi siswa

(2) Meningkatkan kemampuan memecahkan masalah

(3) Meningkatkan kolaborasi
(4) Meningkatkan keterampilan mengelola sumber

(5) Meningkatkan keaktifan siswa

(6) Meningkatkan keterampilan siswa dalam mencari informasi

(7) Mendorong siswa untuk mengembangkan keterampilan komunikasi

(8) Memberikan pengalaman kepada siswa dalam mengorganisasi proyek

(9) Memberikan pengalaman dalam membuat alokasi waktu untuk menyelesaikan tugas

b) Kekurangan penilaian tugas (proyek/project)

Berikut kekurangan penilaian tugas (proyek/projek) sebagaimana yang diungkapkan oleh Kementrian Pendidikan dan Kebudayan (2013 : 4) :

(1) Memerlukan banyak waktu untuk menyelesaikan masalah.

(2) Membutuhkan biaya yang cukup banyak.

(3) Banyak instruktur yang merasa nyaman dengan kelas tradisional, di mana instruktur memegang peran utama di kelas.

(4) Banyaknya peralatan yang harus disediakan.

(5) Peserta didik yang memiliki kelemahan dalam percobaan dan pengumpulan informasi akan mengalami kesulitan.

(6) Ada kemungkinan peserta didik yang kurang aktif dalam kerja kelompok.

(7) Ketika topik yang diberikan kepada masing-masing kelompok berbeda, dikhawatirkan peserta didik tidak bisa memahami topik secara keseluruhan

Portofolio didefinisikan sebagai penilaian yang sistematis dari hasil karya siswa sepanjang waktu tertentu. Ringkasnya menurut Popham (dalam Warsono dan Hariyanto, 2012 : 282), portofolio adalah koleksi yang sistematis dari karya siswa. Portofolio merupakan kumpulan tugas-tugas yang dikerjakan peserta didik. Dengan demikian, dapat dikemukakan bahwa penilaian portofolio adalah penilaian terhadap seluruh tugas yang dikerjakan peserta didik dalam mata pelajaran tertentu (Mulyasa, 2013 : 148).

Suherman (dalam Nurkholis, 2012 : 106) mendefinisikan portofolio sebagai kumpulan bukti fisik kinerja (individu atau kelompok) sebagai data otentik dari aktivitas yang dilakukan. Lee (dalam Nurkholis, 2012 : 106) menjelaskan bahwa portofolio adalah kompilasi bukti menunjukkan kemajuan akademik, prestasi, ketrampilan, dan sikap. 
Ditambahkan bahwa bukti pada portofolio dikoleksi pada periode tertentu. Pranata (2004) menyatakan bahwa penilaian portofolio mampu menghargai siswa sebagai individu yang dinamis, aktif mengkonstruksi pengetahuan sesuai dengan pengalamannya yang spesifik. Di samping itu, penilaian portofolio memandang bahwa penilaian merupakan bagian utuh dari belajar, sehingga pembelajaran dilaksanakan dengan cara memberikan tugas-tugas yang menuntut aktivitas belajar yang bermakna serta menerapkan apa yang dipelajari dalam konteks nyata.

Surapranata dan Hatta (2004 : 28) mengatakan bahwa penilaian portofolio secara sederhana dapat diartikan sebagai kumpulan karya atau dokumen peserta didik yang tersusun secara sistemtis dan terorganisir yang diambil selama proses pembelajaran, digunakan oleh guru dan peserta didik untuk menilai dan memantau perkembangan pengetahuan, keterampilan, dan sikap peserta didik dalam mata pelajaran tertentu.

Mulyadi (2010:101) mengatakan penilaian portofolio merupakan penilaian berkelanjutan yang didasarkan pada kumpulan informasi yang menunjukan perkembangan kemampuan murid dalam satu periode tertentu. Informasi perkembangan murid.

Kelebihan dan kelemahan penilaian portofolio (Sanjaya, 2008 : 369 - 370) :

a) Kelebihan penilaian portofolio

(1) Penilaian portofolio dapat menilai kemampuan siswa secara menyeluruh.

(2) Penilaian portofolio dapat menjamin akuntabilitas (pertanggungjawaban).

(3) Penilaian portofolio merupakan penilaian yang bersifat individual.

(4) Penilaian portofolio merupakan penilaian yang terbuka.

(5) Penilaian portofolio bersifat self evaluation.

b) Kelemahan penilaian portofolio

(1) Memerlukan waktu dan kerja keras.

(2) Penilaian portofolio memerlukan perubahan cara pandang

(3) Penilaian portofolio memerlukan gaya belajar.

(4) Penilaian portofolio memerlukan perubahan sistem pembelajaran.

Ada beberapa perbedaan esensial antara penilaian tugas dengan penilaian portofolio sebagai alat penilaian, secara ringkas dapat dilihat pada tabel di bawah ini (Sanjaya, 2008 : 365) :

Tabel 1

Perbedaan Penilaian Tugas dengan Penilaian Portofolio

\begin{tabular}{|c|c|}
\hline Penilaian tugas & Penilaian portofolio \\
\hline $\begin{array}{l}\text { a) Menilai peserta didik } \\
\text { berdasarkan sejumlah tugas } \\
\text { yang terbatas. }\end{array}$ & $\begin{array}{l}\text { a) Menilai peserta didik berdasarkan seluruh } \\
\text { tugas dan hasil kerja yang berkaitan dengan } \\
\text { kinerja yang dinilai. }\end{array}$ \\
\hline $\begin{array}{lll}\text { b) Menilai } & \text { hanya } & \text { guru } \\
\text { berdasarkan } & \text { masukan } & \text { yang } \\
\text { terbatas. } & & \\
\end{array}$ & b) Mewujudkan proses nilai yang kolaboratif. \\
\hline $\begin{array}{l}\text { c) Menilai semua peserta didik } \\
\text { dengan menggunakan satu } \\
\text { kriteria. }\end{array}$ & $\begin{array}{l}\text { c) Menilai setiap peserta didik berdasarkan } \\
\text { pencapaian } \text { masing-masing } \\
\text { mempertimbangkan juga faktor perbedaan } \\
\text { individual. }\end{array}$ \\
\hline
\end{tabular}




\begin{tabular}{|c|c|}
\hline Penilaian tugas & Penilaian portofolio \\
\hline $\begin{array}{l}\text { d) Proses penilaian tidak } \\
\text { kolaboratif (tidak ada kerja } \\
\text { sama terutama antara guru, } \\
\text { peserta didik dan orang tua). }\end{array}$ & $\begin{array}{l}\text { d) Peserta didik turut serta dalam menilai } \\
\text { kemajuan yang dicapai dalam penyelesaian } \\
\text { berbagai tugas dan perkembangan yang } \\
\text { berlangsung selama proses pembelajaran. }\end{array}$ \\
\hline $\begin{array}{l}\text { e) Penilaian diri oleh peserta didik } \\
\text { bukan merupakan suatu tujuan. }\end{array}$ & $\begin{array}{l}\text { e) Peserta didik menilai dirinya sendiri menjadi } \\
\text { satu tujuan. }\end{array}$ \\
\hline $\begin{array}{l}\text { f) Yang mendapat perhatian } \\
\text { dalam penilaian } \\
\text { pencapaian }\end{array}$ & $\begin{array}{l}\text { f) Yang mendapat perhatian dalam penilaian } \\
\text { meliputi kemajuan, usaha, dan pencapaian. }\end{array}$ \\
\hline $\begin{array}{l}\text { g) Berhubungan antara kegiatan } \\
\text { pembelajaran, penilaian, dan } \\
\text { pengajaran. }\end{array}$ & $\begin{array}{l}\text { g) Terkait erat antara kegiatan penilaian, } \\
\text { pengajaran, dan pembelajaran. }\end{array}$ \\
\hline
\end{tabular}

Berdasarkan definisi diatas, maka penulis mencoba menetapkan hipotesis yang tidak terlepas dari asumsi yang telah ditetapkan terlebih dahulu, yaitu :

$\mathrm{H}_{0}$ : Siswa tidak mampu berpikir kreatif matematis dalam pembelajaran matematika dengan menggunakan penilaian tugas.

$\mathrm{H}_{\mathrm{a}}$ : Siswa mampu berpikir kreatif matematis dalam pembelajaran matematika dengan menggunakan penilaian tugas

\section{METODOLOGI PENELITIAN}

Penelitian ini akan dilaksanakan di

SMP Negeri 2 Kota Cirebon yang beralamat di Jalan Siliwangi No. 94 Tlp. 203075 Kota

Cirebon 45124. Dalam penelitian ini yang akan menjadi sasaran penelitian adalah siswa kelas VIII.

Sejalan dengan tujuan penelitian yaitu untuk mengetahui perbandingan kemampuan berpikir kreatif matematika siswa antara yang menggunakan penilaian tugas dengan penilaian portofolio dalam pembelajaran matematika pada pokok bahasan sistem koordinat, maka metode penelitian yang digunakan adalah metode penelitian kuantitatif.
Dalam penelitian ini menggunakan desain eksperimen yang digunakan dalam penelitian ini adalah yaitu post test. Jadi, dalam model ini terdapat kelompok eksperimen dan kelompok control, dimana pengambilannya dilakukan secara random. Antara kelompok eksperimen dan kelompok kontrol diberi perlakuan yang berbeda.

$$
\text { Adapun judul skripsi ini }
$$
menggunakan (desain) penelitian yang disesuaikan dengan variabel yang diteliti, yaitu :

Variabel bebas :Penggunaan penilaian tugas dengan penilaian portofolio.

Variabel terikat :Kemampuan berpikir kreatif matematika siswa. 
Kemampuan berpikir kreatif matematika siswa diperoleh dari perbandingan berdasarkan selisih rata-rata post test-pre test.

Desain Desain Penelitian posttestonly control desigen (Sugiyono, $2007: 112$ ) :

$$
\frac{\mathrm{E}_{\mathrm{a}} \mathrm{X}_{\mathrm{a}} \mathrm{O}_{2}}{\mathrm{E}_{\mathrm{b}} \mathrm{X}_{\mathrm{b}} \mathrm{O}_{2}}
$$

Keterangan :

$$
\begin{array}{rll}
\mathrm{E}_{\mathrm{a}} & : \text { Kelompok eksperimen } \\
& & \text { penilaian tugas } \\
\mathrm{E}_{\mathrm{b}} & : & \text { Kelompok eksperimen } \\
& & \text { penilaian portofolio } \\
\mathrm{O}_{2} \quad: & \text { Tes akhir (pos-test) } \\
\mathrm{X}_{\mathrm{a}} \quad: & \text { Penilaian tugas. } \\
\mathrm{X}_{\mathrm{b}} \quad: & \text { Penilaian portofolio. }
\end{array}
$$

Adapun teknik analisis yang digunakan antara lain:

1. Uji normalitas

Uji normalitas dilakukan untuk mengetahui normal atau tidaknya distribusi sampel yang diteliti. Uji normalitas yang digunakan yaitu uji Liliefors dengan rumus;

$\mathrm{Zi}=\frac{\mathrm{X}-\overline{\mathrm{x}}}{\mathrm{SD}}$

Keterangan :

$\begin{array}{lll}\mathrm{Zi} & : & \text { skor baku } \\ \overline{\mathrm{X}} & : & \text { nilai rata-rata } \\ \mathrm{X} & : & \text { skor data } \\ \mathrm{SD} & : & \text { standar deviasi }\end{array}$

2. Uji homogenitas

Pengujian dilakukan dengan uji homogenitas dua varians, rumus uji homogenitas yang digunakan adalah uji Fisher, yaitu :

$\mathrm{W}=\frac{\mathrm{S}_{1}^{2}}{\mathrm{~S}_{2}^{2}}$ dimana $\mathrm{S}^{2}=\frac{\mathrm{n} \sum \mathrm{X}^{2}-(\mathrm{X})^{2}}{\mathrm{n}(\mathrm{n}-1)}$

Keterangan :

F : homogenitas

$\mathrm{S}_{1}^{2} \quad$ : varians terbesar atau data pertama

$S_{2}^{2} \quad$ : varians terkecil atau data kedua

3. Analisis data angket

Pengolahan data angket menggunakan rumus berikut ini

(Riduwan, 2013 : 89) :

$$
\mathrm{P}=\frac{X}{A} \times 100 \%
$$

P : Prosentase

$\mathrm{X}$ : Jumlah skor yang

diperoleh

A : Skor maksimal

Tabel 2

Kriteria Angket

\begin{tabular}{|c|c|}
\hline Prosentase & Kriteria \\
\hline $0 \%-20 \%$ & Sangat Lemah \\
\hline $21 \%-40 \%$ & Lemah \\
\hline $41 \%-60 \%$ & Cukup \\
\hline $61 \%-80 \%$ & Kuat \\
\hline $81 \%-100 \%$ & Sangat kuat \\
\hline
\end{tabular}




\section{HASIL DAN PEMBAHASAN}

Berdasarkan analisis data yang telah diolah didapatkan hasil deskripsi penelitian sebagai berikut:

Tabel 3

Hasil Penelitian

\begin{tabular}{|l|l|l|}
\hline \multicolumn{1}{|c|}{ Indikator } & Eksperimen 1 & Eksperimen 2 \\
\hline Berpikir Lancar & $81,33 \%$ & $82,22 \%$ \\
\hline Berpikir Luwes & $76 \%$ & $82,67 \%$ \\
\hline Berpikir Original & $74,67 \%$ & $79,55 \%$ \\
\hline Keterampilan mengelaborasi & $70,22 \%$ & $76 \%$ \\
\hline Keterampilan Menilai & $72,89 \%$ & $79,11 \%$ \\
\hline
\end{tabular}

Hasil berpikir lancar pada eksperimen 1 diperoleh rata-rata presentase dalam berpikir lancar pada tes $81,33 \%$ artinya bahwa siswa dapat menemukan banyak jawaban dan dapat memahami materi pembelajaran dengan baik. Sedangkan pada eksperimen 2 diperoleh rata-rata presentase dalam berpikir lancar pada tes $82,22 \%$ artinya bahwa siswa dapat menemukan banyak jawaban dan dapat memahami materi pembelajaran dengan baik.

Hasil berpikir luwes pada eksperimen 1 diketahui rata-rata presentase dalam berpikir lancar pada tes 76,00 \% artinya bahwa siswa dapat menghasilkan penafsiran terhadap suatu masalah dan menemukan kemungkinan jawaban baik. Sedangkan pada eksperimen 2 diketahui Dengan demikian, rata-rata presentase dalam berpikir lancar pada tes 82,67 \% artinya bahwa siswa dapat menghasilkan penafsiran terhadap suatu masalah dan menemukan kemungkinan jawaban baik.

Hasil berpikir original pada eksperimen 1 dihasilkan rata-rata presentase dalam berpikir original pada tes $74,67 \%$ artinya bahwa siswa dapat mencetuskan ide dan mampu menginterpretasikan sendiri dengan baik. Sedangkan pada eksperimen 2 dihasilkan rata-rata presentase dalam berpikir original pada tes $79,55 \%$ artinya bahwa siswa dapat mencetuskan ide dan mampu menginterpretasikan sendiri dengan baik.

Hasil berpikir keterampilan mengelaborasi pada eksperimen 1 diketahui rata-rata presentase dalam keterampilan mengelaborasi pada tes $70,22 \%$ artinya bahwa siswa dapat mengembangkan suatu masalah. Sedangkan pada eksperimen 2 diketahui rata-rata presentase dalam keterampilan mengelaborasi pada tes 76,00 $\%$ artinya bahwa siswa dapat mengembangkan suatu masalah.

Dan keterampilan menilai pada eksperimen 1 diketahui rata-rata presentase dalam keterampilan menilai pada tes $72,89 \%$ artinya bahwa siswa dapat mengetahui patokan menilai sendiri. Sedangkan pada eksperimen 2 diketahui rata-rata presentase dalam keterampilan menilai pada tes $79,11 \%$ artinya bahwa siswa dapat mengetahui patokan menilai sendiri.

Hasil yang diperoleh dalam uji normalitas data hasil penelitian setelah pembelajaran dengan menggunakan penilaian tugas adalah sebagai berikut :

$$
\begin{aligned}
& \text { Lhitung }\left(\mathrm{L}_{0}\right)=0,1282 \quad \text { (lihat } \\
& \text { lampiran) } \\
& \mathrm{L}_{\text {tabel }}\left(\mathrm{L}_{\mathrm{t}}\right)=0,1320 \text { Dengan }
\end{aligned}
$$

demikian, karena $\mathrm{L}_{0}<\mathrm{L}_{\mathrm{t}}$

maka hipotesis nol $\left(\mathrm{H}_{0}\right)$ diterima, yaitu data hasil penelitian setelah pembelajaran dengan menggunakan penilaian tugas berdistribusi normal.

Dari hasil perhitungan uji homogenitas didapat $\mathrm{F}_{\text {hitung }}<\mathrm{F}_{\text {tabel, }}$ yaitu $\mathrm{F}_{\text {hitung }}=0,589$ sedangkan $\mathrm{F}_{\text {tabel }}=1,650 . \mathrm{Hal}$ ini berarti pada taraf signifikansi $\alpha=0,05(5 \%)$ $\mathrm{H}_{0}$ diterima. Dengan demikian dapat disimpulkan bahwa kedua sampel tersebut berasal dari populasi berdistribusi homogen.

Hasil yang diperoleh dari penghitungan respon siswa yang diberikan perlakuan menggunakan penilaian tugas terhadap kemampuan berpikir kreatif matematika siswa adalah dari 45 siswa 29 diantaranya memberikan respon kuat setelah menggunakan penilaian tugas, dengan rata-rata prosentase $61 \%$ - 80\%, dan 16 siswa lainnya memberikan respon sangat kuat setelah menggunakan penilaian tugas dengan rata-rata prosentase $81 \%-100 \%$. 
Tabel 4

Hasil Uji Tes "t” Kelompok 1 dan Kelompok 2

\begin{tabular}{|l|c|c|c|c|}
\hline \multicolumn{1}{|c|}{ Variabel } & $\begin{array}{c}\text { Jumlah } \\
\text { sampel }\end{array}$ & thitung & t tabel & $\begin{array}{c}\text { Kesimpulan } \\
\text { Data }\end{array}$ \\
\hline $\begin{array}{l}\text { Kemampuan } \\
\text { berpikir kreatif } \\
\text { matematika siswa } \\
\text { kelompok 1 dan } \\
\text { kelompok 2 }\end{array}$ & 90 & $-4,557$ & 1,987 & $\begin{array}{c}\mathrm{H}_{0} \text { diterima } \\
\text { dan } \mathrm{H}_{\mathrm{a}} \text { ditolak }\end{array}$ \\
\hline
\end{tabular}

Dengan demikian penelitian ini bisa menguji kebenaran hipotesis 3, artinya bahwa tidak terdapat perbedaan yang signifikan antara yang menggunakan penilaian tugas (proyek/project) dengan penilaian portofolio terhadap kemampuan berpikir kreatif matematika siswa SMP Negeri 2 Kota Cirebon.

\section{PEMBAHASAN}

Perbedaan

skor rata-rata

kemampuan berpikir kreatif matematika siswa setelah pembelajaran dengan menggunakan penilaian tugas (proyek/project) dengan setelah pembelajaran menggunakan penilaian portofolio yaitu 74,31 untuk skor rata-rata kemampuan berpikir kreatif matematika siswa yang menggunakan penilaian tugas (proyek/project) dan 79,69 untuk skor ratarata kemampuan berpikir kreatif matematika siswa yang menggunakan penilaian portofolio. Hal ini membuktikan bahwa kemampuan berpikir kreatif matematika siswa yang menggunakan penilaian tugas (proyek/project) dengan yang menggunakan penilaian portofolio tidak terdapat perbedaan yang signifikan.

Pembelajaran dengan penilaian tugas (proyek/project) juga meningkatkan antusiasme untuk belajar. Ketika anak-anak bersemangat dan antusias tentang apa yang mereka pelajari, mereka sering mendapatkan lebih banyak terlibat dalam subjek dan kemudian memperluas minat mereka untuk mata pelajaran lainnya. Antusias peserta didik cenderung untuk mempertahankan apa yang mereka pelajari, bukan melupakannya secepat mereka telah lulus tes.

Disamping itu pula pada pembelajaran menggunakan penilaian tugas (proyek/project) merupakan investigasi mendalam tentang sebuah topik dunia nyata, hal ini akan berharga bagi atensi dan usaha peserta didik. Mengingat bahwa masingmasing peserta didik memiliki gaya belajar yang berbeda, maka pembelajaran berbasis proyek memberikan kesempatan kepada para peserta didik untuk menggali konten (materi) dengan menggunakan berbagai cara yang bermakna bagi dirinya, dan melakukan eksperimen secara kolaboratif. Pembelajaran dengan penilaian tugas (proyek/project) ini juga menuntut siswa untuk mengembangkan keterampilan seperti kolaborasi dan refleksi. Pengujian hipotesis melalui uji-t juga memperlihatkan skor siswa yang menggunakan penilaian tugas (proyek/project) dengan penilaian portofolio memperlihatkan bahwa tidak ada perbedaan yang signifikan kemampuan berpikir kreatif matematika siswa.

\section{KESIMPULAN DAN SARAN}

Berdasarkan analisis data pengujian hipotesis, maka penulis dapat mengambil sebuah kesimpulan bahwa :

1. Siswa mampu berpikir kreatif matematis dalam pembelajaran matematika dengan menggunakan penilaian tugas.

2. Siswa mampu berpikir kreatif matematis dalam pembelajaran matematika dengan menggunakan penilaian portofolio.

3. Tidak ada perbedaan yang signifikan dalam kemampuan berfikir kreatif matematika siswa antara yang menggunakan penilaian tugas dengan penilaian portofolio dalam pembelajaran matematika

Berdasarkan hasil penelitian dan dengan memperhatikan kesimpulan diatas, berikut diajukan beberapa saran :

1. Dalam proses pembelajaran, guru hendaknya memiliki pengetahuan dan kemampuan yang memadai untuk memilih metode pembelajaran dan penilaian yang tepat dan sesuai dengan materi yang akan diajarkan

2. Sebaiknya para guru dapat mengembangkan penilaian tersebut 
menjadi lebih bervariasi, lebih menarik dan lebih mudah diterapkan

3. Perlu adanya penelitian lebih lanjut untuk mengetahui apakah penggunaan penilaian tugas dengan penilaian portofolio dalam pembelajaran dapat meningkatkan kemampuan berpikir kreatif matematika siswa sehingga berdampak positif terhadap hasil belajar yang diperoleh siswa

\section{DAFTAR PUSTAKA}

Arikunto, Suharsimi. 2010. Prosedur Penelitian (Suatu Pendekatan Praktik). Jakarta: PT Rineka Cipta

Iskandar. 2012. Psikologi Pendidikan (Sebuah Orientasi Baru). Jakarta Selatan: Referensi

Jamaris, Martini. 2013. Orientasi Baru dalam Psikologi Pendidikan. Bogor: Ghalia Indonesia

Jazuli, Akhmad. 2009. Berpikir Kreatif Dalam Kemampuan Komunikasi Matematika. (Disampaikan Dalam Seminar Nasional Matematika dan Pendidikan Matematika). Purwokerto: Program Studi Pendidikan Matematika Universitas Muhammadiyah Purwokerto. Jurnal (Online). Tersedia di : httpeprints.uny.ac.id70251P11-

Akhmad\%20Jazuli.pdf. Diakses pada tanggal 13 Agustus 2014 Pukul 9.35 WIB

Mulyadi. 2010. Evaluasi Pendidikan (Pengembangan Model Evaluasi Pendidikan Agama di Sekolah). Malang: UIN-Malik Press

Mulyasa, E. 2013. Pengembangan dan Implementasi Kurikulum 2013. Bandung: PT. Remaja Rosdakarya

Muslich, Masnur. 2011. Authenticc Assesment: Penilaian Berbasis Kelas dan Kompetensi. Bandung: PT Refika Aditama

Muslich, Masnur. 2011. KTSP Pembelajaran Berbasis Kompetensi dan Konstektual. Jakarta: Bumi Aksara

\footnotetext{
Nurhayati, Eti. 2010. Bimbingan Keterampilan Belajar \& Kemandirian Belajar. Bandung: Batic Press

Nurhayati, Eti. 2011. Psikologi Pendidikan Inovatif. Yogyakarta: Pustaka Pelajar.
}

Nurkholis, Aris. 2012. Penilaian Portofolio Dalam Pembelajaran Matematika Berbasis Kontekstual Pada Siswa Kelas 1 SD Juara Yogyakarta Tahun Ajaran 2011/2012 (Disampaikan dalam Seminar Nasional Matematika dan Pendidikan Matematika dengan tema " Kontribusi Pendidikan Matematika dan Matematika dalam Membangun Karakter Guru dan Siswa" pada tanggal 10 November $2012 d i$ Jurusan Pendidikan Matematika FMIPA UNY). Jurnal (Online). Tersedia di : httpeprints.uny.ac.id74991P\%20\%2011.pdf. Diakses pada tanggal 30 Agustus 2014 Pukul 21: 21 WIB.

Priyatno, Duwi. 2011. Buku Saku SPSS Analisis Statistik Data Lebih Cepat, Efesien, dan Akurat. Jakarta: PT Buku Seru

Riduwan. 2013. Belajar Mudah Penelitian Untuk Guru-Karyawan dan Peneliti Pemula. Bandung: Alfabeta

Sanjaya, Wina. 2008. Kurikulum dan Pembelajaran. Jakarta: Kencana Prenada Media Group Sugiyono. 2007. Metodologi Penelitian Pendidikan: Pendekatan Kuantitatif Kualitatif, dan R\&D. Bandung: Alfabeta

Surapranata Sumarna, Hatta Muh. 2004. Penilaian Portofolio Implementasi Kurikulum 2004. Bandung: PT. Remaja Rosdakarya

Warsono, Hariyanto. 2012. Pembelajaran Aktiv Teori dan Asessmen. Bandung: PT Remaja Rosdakarya Widyantini Theresia. 2014. Penerapan Model Projec Based Learning (Model Pembelajaran Berbasis Proyek) Dalam Materi Pola Bilangan Kelas Empat. Yogyakarta: Pusat Pengembangan dan Pemberdayaan Pendidikan dan Tenaga Kependidikan (PPPPTK) Matematika. Artikel (Online) tersedia httpp4tkmatematika.orgfileARTIKE LArtikel\%20MatematikaPenerapan $\% 20$ Model\%20Project\%20Based\%20L earning.pdf. Diakses 28 Oktober 2014 jam 01:03 WIB.

Yusuf, Abu Al-Hajjaj. 2010. 30 Kiat Meledakan Kreativitas Anda Kreatif atau Mati. Surakarta: Al-Jadid 